\title{
Health Diplomacy As A Soft Power: What COVID-19 Has Taught Us?
}

\author{
Dr. Omkolthoum ElSayed \\ Health Policy Advisor
}

\section{Background}

Health Diplomacy is now important more than ever. It's a complex and multi-dimensional concept. One example is when health researchers and health policy advisors come together for complex multinational projects in health. They need diplomatic agreements that require negotiations between the nations to come up with a universal agreement based on scientific evidence.

There are various examples of the opposite direction where health was used as a tool to achieve national interest. This direction recently gained more attention during the current COVID-19 pandemic.

The concept of soft power was defined by the American political scientist Joseph Nye as the "power of cooperation by which a country can exert influence by playing the seduction and persuasion, its objective being to bring others to share its values, to reproduce its models, to think like it." According to this definition, a country mobilizes resources such as its image, reputation, prestige, the attractiveness of cultures, science, technology profile, etc. to gain power. This can take many forms and approaches, such as higher education (Harvard or Ecole Nationale d'Administration), filmmaking (Hollywood), humanitarian action (French doctors), and so on.

This paper aims to shed light on health diplomacy's role, exploring the Egyptian case, and some Asian and global lessons to learn from.

\section{Keywords}

Health Diplomacy, COVID-19, Soft Power, Egypt

\section{First, let's understand the concept of Soft Power}

The soft power theory was developed by Nye 2005 when he proposed that soft power consists of a country's history, geography, cultural diversity, economic strength, social pattern, democratic development, civil society organizations' prevalence, and impacts, science and technology 
infrastructure, and values like art and sports which the social life produced in the intellectual sense. According to Nye, soft power behaved differently than other traditional forms of power, i.e., military power. Therefore, soft power employs different tools in order to achieve its goals.

\begin{tabular}{|c|c|c|c|}
\hline Power Types & Behaviors & Basic Tools & Government Policies \\
\hline Military power & $\begin{array}{l}\text { " Coercion } \\
\text { * Deterrence } \\
\text { * Protection } \\
\end{array}$ & $\begin{array}{l}{ }^{*} \text { Threat } \\
{ }^{*} \text { Force }\end{array}$ & $\begin{array}{l}\text { "Coercive Diplomacy } \\
\text { * War } \\
\text { " Alliance }\end{array}$ \\
\hline $\begin{array}{l}\text { Economic } \\
\text { Power }\end{array}$ & $\begin{array}{l}\text { "Encouragement } \\
{ }^{*} \text { Coercion } \\
\text { " Admirableness }\end{array}$ & $\begin{array}{l}\text { * Money-Making } \\
\text { * Investment } \\
{ }^{\star} \text { Values, Culture }\end{array}$ & $\begin{array}{l}\text { * Help } \\
\text { * Bribery } \\
\text { " Public Diplomacy }\end{array}$ \\
\hline Soft Power & $\begin{array}{l}\text { Creating } \\
\text { Agenda }\end{array}$ & $\begin{array}{l}\text { * Policies } \\
\text { * Institutions }\end{array}$ & $\begin{array}{l}\text { * Bilateral and Multilateral } \\
\text { Diplomacy }\end{array}$ \\
\hline
\end{tabular}

Classification of Power in the International Order (Nye, 2005)

Geun Lee built on that work and defined soft power according to its resources. So, power is as soft power when soft, non-material resources are used, whereas power is hard when material resources are used. Therefore, he called it a "resource-based theory of soft power" (Lee, 2009). Besides, Lee proposes a model of how soft resources can be diverted into soft power.

(1) Application of soft resources $=>$ Fear $=>$ Coercive power (or resistance)

(2) Application of soft resources $=>$ Attractiveness, Safety, Comfort, Respect $=>$ Co-optive power

(3) Application of soft resources (theories, interpretative frameworks) $=>$ New ways of thinking and calculating $=>$ Co-optive power

(4) Socialization of the co-optive power in the recipients => Long term soft power in the form of "social habits"

Diversion from soft resource to soft power (Lee 2009) 


\section{So, What do we mean by Health Diplomacy as a soft pow- er?}

One of the soft power approaches that received increased attention globally is science diplomacy. This attention appeared in the Science and Technology (S\&T) policies that became a subject of supranational governance in the Maastricht Treaty of 1992 of the European Union, which stipulated a multi-layered governance system for S\&T, that is defined as a domain for everyday activities and programs. The European Commission (EC) has shown a tendency to engage S\&T in its foreign policy and deployed several S\&T counsellors in the European Union's missions abroad.

In the same direction comes the practice of health diplomacy, which refers to a system of organization, communication, and negotiation processes that shape the global policy environment in the sphere of health and its determinants. It brings together several disciplines, including public health, international affairs, management, law, economics, and trade policy. It relates to health issues and determinants that go beyond country boundaries limitations, are international in nature, and need global consensus to address them. As a practice, health diplomacy has been carried out for hundreds of years when early concepts of quarantine were introduced, but the term itself is relatively new.

\section{Applications of Health Diplomacy}

The HIV/AIDS epidemic, the severe acute respiratory syndrome (SARS), avian influenza, the Ebola outbreak, and most recently, the COVID-19 outbreak have highlighted the importance of internationally coordinated responses in overcoming national and regional health challenges. More examples illustrated in Europe in the late 1980s, when the Member States launched the first-ever collaboration to take away the most substantial environmental threats to human health, with a series of ministerial conferences coordinated by the WHO Regional Office for Europe. As a result, there is a better understanding of the multiple determinants of health and the importance of engaging non-health actors for better health and well-being for all. These actors include the whole government and society, which is referred to as "the health in all policies." This approach is essential in combating the current challenges of antimicrobial resistance and the health problems of migrants and refugees. Besides, there were multiple reviews over the General Agreement on Trade in Services (GATS) and other WTO agreements from a health policy 
perspective.

The prominent models developed for successful health diplomacy practices were creating the Pasteur Institute network of laboratories (in Francophone countries) and the cooperation between Dr. Albert Sabin from the US and Dr. Mikhail Chumakov from the USSR (Russia now) during the Cold War to develop the oral polio vaccine. In these examples, diplomacy and foreign policy tools were used to achieve the global health agenda.

In a more recent formal change to health diplomacy, Switzerland became the first country to set common health and foreign policy goals in 2006. The Federal Council (the Swiss Government) adopted the first Swiss Health Foreign Policy in 2012. The policy defines 20 goals and tools for effective inter-ministerial collaboration. Moreover, in 2007 foreign ministers from Brazil, France, Indonesia, Norway, Senegal, South Africa, and Thailand issued the "Oslo Ministerial Declaration" that linked global health to foreign policy.

\section{Directions of Health Diplomacy}

These observed practices worldwide show that there have been two directions of health diplomacy; the direction of the foreign policy for health where health is the goal of efforts exerted by health and nonhealth actors as well as the practice of state and non-state actors that attempt to coordinate global policy solutions to improve global health, as seen in the production of Polio vaccine example.

The other observed direction is the health for a foreign policy where health diplomacy actions are aligned with the country's foreign policy goals. This direction raises questions about the potential effect on the global health agenda, whether health is used as a political tool to serve foreign policy goals and to defend national interests, and to what extent health diplomacy could be an effective tool of a country's foreign policy?

Available literature shows more about the foreign policy for the health direction of health diplomacy and little about the second direction of health for foreign policy; however, practices and government policies show that the second direction has more to tell us.

For example, even though Pasteur Institute network of laboratories was launched as a response of Pasteur's vision stated in his speech at the inauguration of his institute in Paris in 1888, he said that "science knows no country because knowledge belongs to humanity and is the torch which illuminates the world", despite this universal nature of his mes- 
sage, the network widely spread in Francophone countries. This paradox draws attention to the effect of foreign policy on health and how health is used to serve the country's foreign policy goals.

In addition, scientific cooperation is considered as an essential sphere of French influence/soft power. As a feature of increasing attention to science diplomacy, the French parliamentary bill on France's foreign activities was adopted in 2010. The government would submit a report proposing strengthening the cohesiveness of the state promotion of international technical expertise. Moreover, each diplomatic mission develops a specific policy on scientific cooperation and takes charge of disseminating it to the relevant institutions and organizations in France. In 2015, there were nine counsellors and seventy-two attachés (thirty-one attachés for science and technology, with ten Institute Pasteur in Africa and the Middle East, which reflects the importance of a ground presence in France's traditional regions of influence.

In Egypt, there are observed actions that show some features of using health for foreign policy. Examples of these actions are the frequent medical convoys for Nile Basin countries, donating medical supplies (recently for China and more frequent to African countries), building health service providing facilities (recently in Lebanon), etc.

The first direction of health diplomacy, using foreign diplomacy for health, also worked very successfully in Egypt. This was illustrated in late 2013 with the great effort exerted to reduce the price for the supply of the US-manufactured antiviral treatment Sovaldi for less than $1 \%$ of its price. This contributed significantly to the success of the national campaign "100 Million Healthy Lives" to treat virus C (in 2008, one in 10 Egyptians had chronic hepatitis C).

\section{COVID-19 and Health Diplomacy}

The current COVID-19 pandemic has shown the greater importance of health diplomacy worldwide. As early as the declaration of the COVID19 as a global pandemic with an imminent threat, Egypt sent tons of medical supplies to China accompanied by a high-level delegation headed by the Minister of Health to show solidarity and support to the Chinese government. Egypt showed the same solidarity with Italy when it had the highest COVID-19 cases. Similarly, Egypt sent medical supplies to the US and other countries as a sign of support.

The return on investment was unpredictably quick. Egypt was granted the license to manufacture and distribute the antiviral treatment 
Remdesivir in Egypt and in 127 countries. This achievement was a product of the joint effort of the strong local Egyptian pharma industry (Eva Pharma) and the successful Egyptian foreign diplomacy. In addition to that, the Ministry of Health managed to reach an agreement with the Chinese government to manufacture the vaccine, being under clinical trials for the moment, through the national vaccine production company VACSERA. Moreover, Egypt would be the hub for manufacturing the vaccine in Africa.

In China, there was historical attention to health diplomacy. This was illustrated in Africa through the commitment to provide medical supplies and training anti-malaria institutions in Africa. During the Ebola outbreak, China offered emergency humanitarian assistance and participated in developing the African Centres for Disease Control and Prevention, the African Union's health agency.

More recently, there was global pressure and increased blame for China over the COVID-19 pandemic. The Chinese government acted swiftly and strategically to improve the image. China has donated tons of medical supplies and test kits to Italy, Spain, and other countries with the highest COVID-19 cases. At the time of writing, China has provided aid to over 140 countries, sent medical teams overseas, and donated $\$ 50$ million to the WHO (World Health Organization).

China was also keen to share the scientific evidence and data obtained either in publications or through close cooperation with international organizations such as the WHO. Most importantly, the Chinese government shared the genetic sequence of the virus, which was essential to the rapid PCR assays (Polymerase chain reaction) development and sharing globally.

This cooperative behaviour has gained recognition and respect, which helped lower the blaming tone over the pandemic. Besides, it put China in a better position to avoid documented official blames on many occasions.

\section{Conclusion}

As observed in the historical as well as the recent development of health diplomacy practices in Egypt and worldwide, health diplomacy has gained a central position in countries' soft power. These practices have proven to be very effective in achieving national goals and interests. This success encouraged more countries to exert more and more efforts in both directions of health diplomacy. 
Despite the observed increase and successful efforts in Egypt, there is little knowledge about the general framework that maps out these activities. To the author's best knowledge, there is no declared regulatory Egypt health foreign policy or strategy that sets joint health and foreign policy goals. That raises the question about the extent to which health diplomacy can play an effective role in Egypt's foreign policy. The author expects the answer would be a new Egyptian Foreign Policy that entails a coordinated, organized national framework of international cooperation, public health, and effective communication. 


\section{References}

1. Closing the gap in a generation: health equity through action on the social determinants of health. Final report of the Commission on Social Determinants of Health. Geneva: World Health Organization; 2008 (http://www.who.int/ social_determinants/final_report/ csdh_finalreport_2008.pdf, accessed August 2020.).

2. Elgstrom, O., and M. Smith. 2006. The European Union's roles in international politics: concepts and analysis. London: Routledge.

3. Federal Department of Foreign Affairs, Federal Department of Home Affairs, editors. Swiss Health Foreign Policy. Bern: Federal Office of Public Health; 2012.

4. Feldbaum H, Lee K, Michaud J (2010) Global health and foreign policy. Epidemiol Rev 32: 82- 92

5. Foreign Ministers of Brazil, France, Indonesia, Norway, Senegal, South Africa, and Thailand (Oslo) (2007) Oslo Ministerial Declaration- Global health: A pressing foreign policy issue of our time. Lancet 369: 1373-1378.

6. Geun Lee (2009) A theory of soft power and Korea's soft power strategy, Korean Journal of Defense Analysis, 21:2, 205-218,

7. International Health Regulations (2005), 3rd edition. Geneva: World Health Organization; $2016 \quad$ (http://www.who.int/ihr/ publications/9789241580496/en).

8. Kickbusch I, Lokeny M (2013) Global health diplomacy: five years on. Bull World Health Organ 91: 159-159A.

9. Nye, J., 2005. 'On the Rise and Fall of American Soft Power', New Perspectives Quarterly, 22(3),

10. Pasteur International (2014) History in Movement. Available: http:// www.pasteur-inter national.org/ip/easysite/pasteur-internationalen/ institut-pasteur-international-network/ history-in-movement. Accessed August 2020.

11. Philippe Lane. French Scientific And Cultural Diplomacy. 2013. Liverpool University Press.

12. Pierre-Bruno Ruffini. Science and Diplomacy: A New Dimension of International Relations. 2017. Springer International Publishing.

13. Review of social determinants and the health divide in the WHO Eu- 
ropean Region. Final report. Copenhagen: WHO Regional Office for Europe; 2014 (http://www.euro.who.int/en/publications/abstracts/ review-of-socialdeterminants-and-the-health-divide-in-the-whoeuropean-region.-final-report, accessed August 2020).

14. Swanson W (2012) Birth of a cold war vaccine. Sci Am 306: 66-69.

15. The WHO - Coronavirus disease (COVID-2019) situation reports. Available:https://www.who.int/emergencies/diseases/novelcoronavirus-2019/situation-reports/? gclid=EAIaIQobChMIxp_VopWR6wIV1PdRCh1AiARZEAAYASA CEgKf4vD BwE. Accessed August 2020.

16. Tim Flink\& Ulrich Schreiterer. (2010). Science diplomacy at the intersection of S\&T policies and foreign affairs: toward a typology of national approaches. Science and Public Policy, 37(9).

17. Tognotti E (2013) Lessons from the History of Quarantine, from Plague to Influenza A. Emerg Infect Dis 19: 254-259. Available: http://wwwnc. cdc.gov/eid/article/19/2/12-0312_article.htm. Accessed August 2020. 


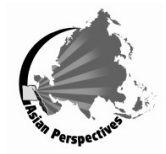

